\title{
Core competencies required of project managers
}

\author{
Michael Birkhead, Margaret Sutherland* \& Tudor Maxwell \\ Graduate School of Business Administration, University of the Witwatersrand, P.O.Box 98, Wits, 2050 South Africa
}

Received June 2000

\begin{abstract}
Project management is internationally recognised as a management tool that is critical for success in the current work environment. In South Africa, initiatives are under way to produce internationally acceptable education and certification standards for the profession. The aim of this study is to identify the competencies and training needs required of project managers operating in South Africa's unique context. A questionnaire based on both previous international studies and personal interviews was administered by e-mail to members of the Project Management Institute of South Africa. Data was received from 128 respondents operating primarily in information technology, construction and engineering fields across the country. The results of the survey establish a rank ordered list of the competencies and training needs of South African project managers, and confirm that project management competencies are generic in nature. The findings are unique to South Africa, and proffer a set of core competencies which has important implications for the certification and training of South African project managers.
\end{abstract}

\section{Introduction}

Project management is a comparatively new branch of general management. Although projects have been used extensively in the construction, space exploration and engineering fields, their application has now spread to a host of different industries (Crawford, 1998). Organisations have recognised the efficacy of projects to create cross-functional teams, and to achieve rapid results within strict time and budget constraints (Peters, 1992). This has made project management a critical and powerful tool in the hands of the modern organisation (Pinto \& Kharbanda, 1996).

Recent research has shown that it is the project manager who emerges as the single overriding factor which decides a project's success or failure (Zimmerer \& Yasin, 1998; Sattler \& Neights, 1998). As more organisations move towards a project-based approach, the demand for project managers has outstripped supply and there is a growing international interest in the selection, training and certification of project managers (Stewart, 1995; Crawford, 1998).

The need for the development of project management competencies in South Africa is made more urgent by the emergence of new technologies and the relaxation of trade regulations, both of which have resulted in a highly competitive marketplace (Cleland, 1991). An initiative has been launched by the National Qualifications Framework (NQF) to develop internationally acceptable training and qualification standards for industry and management (Meyer, 1996). Among these standards are those required for project management, which are to be based on internationally developed competency standards. However, the adoption of international project management standards in South Africa has met with opposition. There have been calls for the development of a qualification which is appropriate to the country's environmental and situational context - taking cognisance of South Africa's social culture, norms and practices (Brown, 1998; Meyer \& Semark, 1996).

The aim of this article is to identify the specific core competencies and current training needs required of project managers operating in South Africa.

\section{Literature review}

\section{Competencies}

The use of the term 'competence' is becoming increasingly prevalent in the field of training and certification. Despite the attention, however, much of the published work on competencies reveals considerable ambiguity surrounding the notion (Stewart \& Hamlin, 1992; Woodruffe, 1993). As a working definition, 'competency' can be taken to comprise two elements - the actual performance of a required skill, and the personal attributes which underlie such performance.

Competency-based standards for management have been adopted in several countries, including the United States, Canada, the United Kingdom, New Zealand and Australia (Garrick \& McDonald, 1992). These standards use the same underlying process. They all seek to identify and cluster competencies that are necessary for an employee to perform effectively in a particular job. Then performance criteria are defined, along with appropriate units of measurement (Garrick et al., 1992).

The primary criticism that has been raised against competency standards in management is that they are performancebased; they define competencies as measurable behaviours that are demonstrated in a specific environment. This approach excludes intangible qualities that are difficult to observe and measure directly (Stewart \& Hamlin, 1992; Wills, 1993; Brown, 1993). As an alternative to using competency standards, authors such as Boyatzis (1982) and Tumer \& Crawford (1992) define competencies in terms of unconscious personal characteristics and traits. They contend that personal attributes are more important than actual performance in influencing job success. Their definitions include motivations, values and attitudes. There is a growing awareness of the need to acknowledge these attributional competencies, and the contribution that personal values and attitudes make towards improving managerial performance (Meyer et al., 1996; Crawford, 1998; Toney, 1998). This research will therefore incorporate all competencies which impact on improved performance, including skills, knowledge, attitudes, behaviours, and values. 


\section{Project management}

Early forms of project management in the construction and engineering fields were developed to improve planning and cost controls (Harrison, 1983; Crawford, 1998). Owing to the success of such strategies in these high-risk sectors, use of project management spread to associated high technology fields such as information technology. The drive towards global competitiveness has now stimulated the spread of project management into every industry (Brown, 1998; Zimmerer \& Yasin, 1998).

It is widely accepted that general management skills provide a foundation for project management skills (Thamhain, 1991; Pettersen, 1991). However, project management differs from general management in two fundamental aspects. Firstly, every project is a unique undertaking, and secondly, the management of a project is temporary, and has a fixed start, duration and finish (PMI, 1996). Therefore, whereas general management is ongoing and repetitive, project management is primarily concerned with the introduction and management of change, and requires substantially different competencies (Harrison, 1983; Lockyer \& Gordon, 1996).

\section{Previous research into project management}

As project management has developed as a profession globally, various international studies have attempted to identify the skills and behaviours required of project managers. Most early attempts relied on opinion and secondary sources of data (Lockyer \& Gordon, 1996; Eisiendel, 1987; Petterson, 1991). Posner (1987) was among the first authors to publish an empirically grounded study listing the characteristics of an above-average project manager. His research used an open-ended questionnaire, and identified six core skill areas, which he linked to critical project problem areas. He concluded that the training requirements for project managers were mostly interpersonal as opposed to technical in nature. He recommended that project managers should improve their ability to communicate, organise, build teams, provide leadership and deal comfortably with change (Posner, 1987). Zimmerer \& Yasim (1998) and Jiang, Klein \& Margulis (1998) arrived at similar conclusions, and recommended that project managers combine their existing technical competencies with other, 'people-orientated', skills.

Thamhain (1991) conducted a similar study using personal interviews, and identified three principal competency groups for project managers - interpersonal, technical and administrative. He concluded that a project manager's effectiveness depended on the ability to understand the people, the tools and the organisation. Others subsequently confirmed these findings in the field (Reich, 1991; Pinto \& Kharbanda, 1996).

Current research by Crawford (1998) is seeking to assess both the attribute- and performance-based competencies. Her research is part of a three-year study, but a preliminary report has supported the notion of generic standards across international boundaries. However, the results were confined to a comparison between two developed countries, the United States and Australia (Crawford, 1998).

Kooyman \& Sargent (1998) have raised the need to address the differences between project managers operating in different cultural environments. It has also been suggested by Pettersen (1991) that additional competencies would be required by a project manager working in a developing country. Although limited research has been done within particular organisations to identify the competencies required of project managers in South Africa, no publicly available research has been conducted.

\section{Research methodology}

The methodology used to conduct the survey followed an established format used in similar investigations into managerial competencies (Barker, 1992; Cresswell, 1995; Overmeyer, 1997; Frylink, 1998). The research was conducted in three phases, and the data collection instrument was a research questionnaire.

The first phase included an extensive survey of international literature to obtain a list of core competencies applica. ble to project managers. These sources were then subjected to a process of content analysis, and cross-tabulated to identify the most widely accepted competencies.

The second phase comprised eight personal interviews with project managers holding senior positions in private organisations or academic institutions. These interviewees were selected in consultation with the Project Management Institute of South Africa (PMISA) to identify key stakeholders in the profession. The interviews employed open-ended questions to probe for competency requirements specific to the South African context. Although many of the constructs were similar to those identified in the literature survey, nine new competencies were identified. A list of 28 constructs was derived from the literature and personal interviews.

\section{Questionnaire construction}

The questionnaire was constructed in Microsoft Excel using Visual Basic macros, and was divided into three sections. The first section collected each respondent's biographical data. The second section requested respondents to rate the importance of each competency, and to indicate how evident they believed that competency was in the profession. This allowed the identification of the 'gap' between the level at which a competency was required, and the level at which it actually occurred. These ratings were recorded on separate five-point Likert scales graded from 'very high' to 'very low'. The third section of the questionnaire allowed each respondent to include additional competencies which were considered to be relevant to project management.

The questionnaire was pre-tested, and as a result of this feedback, graphic and structural changes were made to the questionnaire to improve its general clarity.

\section{Sample}

It was decided to draw the sample from the Project Management Institute of South Africa (PMISA). The Institute has over 1200 members dispersed across South Africa, who are drawn from a variety of different disciplines, but with a bias towards people employed in the engineering, information technology and construction fields. The sample does not claim to represent all South African project managers.

\section{Data collection}

Following the endorsement of this research undertaking by the Institute, the questionnaire was administered by e-mail to 
all PMISA members with access to electronic mail facilities. A series of problems was encountered with the distribution of the questionnaire, including incompatibility with various computer operating systems, and corruption or rejection by certain of the server firewalls. This might have been as a result of the use of macros in the questionnaire.

\section{Data analysis}

The responses were copied from each questionnaire into a single Microsoft Excel spreadsheet. The resulting data was then analysed in Number Cruncher Statistical System (NCSS) using descriptive statistics, correspondence analysis, factor analysis, paired- and two-sample t-tests.

\section{Research findings}

A total of 155 questionnaire responses, of which 127 were eligible for analysis, was received over a four-week period. Of the respondents, $89 \%$ were male, and there was an almost perfect split between project managers operating in the information technology/information systems field and the construction/engineering field. The respondents also indicated an even spread of qualifications and experience.

\section{Statement evaluation}

Correspondence analysis was used to re-scale the responses from ordinal to interval data, by calculating the Euclidean distance between points on the first two axes, and using these distances to recreate the interval scale ranging from 1 to 5 .
Table 1 Re-scaling of five-point Likert scales (importance and evidence)

\begin{tabular}{lcc}
\hline Adjusted five-point Likert scales & Importance & Evidence \\
\hline Very low & 1 & 1 \\
Low & 1.979 & 2.045 \\
Medium & 2.961 & 3.375 \\
High & 4.176 & 4.500 \\
Very high & 5 & 5 \\
\hline
\end{tabular}

This technique is well documented by Bendixen \& Sandler (1994), and is necessary to make possible parametric statistical manipulation and interpretation of the raw data. This process was conducted independently on both of the Likert scales used in section 2 of the questionnaire, and the results of the conversion are presented in Table 1. The results were verified by examining the plots of the re-scaled data.

It may be observed that the interval scale derived from correspondence analysis was quite different from the original numerical values 1 to 5 attributed to the Likert scale. In particular, there was proof that the 'high' and 'very high' options were perceived by respondents to be closely related, especially when considering the 'evidence' of competencies. It should be noted that the dependant relationship between the 'importance' and 'evidence' scales led to a minor graphical inconsistency in the latter correspondence plot. This was insufficient, however, to be considered prejudicial to the results.

Table 2 Mean rankings of competencies

\begin{tabular}{|c|c|c|c|c|c|c|}
\hline \multirow[t]{2}{*}{ Competency } & \multicolumn{3}{|c|}{ Importance } & \multicolumn{3}{|c|}{ Evidence } \\
\hline & Mean & $\delta$ & Rank & Mean & $\delta$ & Rank \\
\hline $\begin{array}{l}\text { Planning: Identifying objectives and priorities, defining tasks and establishing timetables to } \\
\text { achieve desired goals }\end{array}$ & 4.79 & 0.48 & 1 & 3.73 & 0.9 & 1 \\
\hline $\begin{array}{l}\text { Scope management: The definition of clear objectives and boundaries for the project, and } \\
\text { prevention of unnecessary changes }\end{array}$ & 4.66 & 0.64 & 2 & 3.24 & 0.99 & 15 \\
\hline $\begin{array}{l}\text { Controlling: Maintaining activities in line with project objectives and restraints, and taking } \\
\text { necessary corrective action }\end{array}$ & 4.64 & 0.51 & 3 & 3.63 & 0.87 & 4 \\
\hline $\begin{array}{l}\text { Decisiveness: The propensity to make and commit to decisions in difficult situations while } \\
\text { considering the whole project }\end{array}$ & 4.6 & 0.49 & 4 & 3.48 & 0.91 & 8 \\
\hline $\begin{array}{l}\text { Stakeholder management Understanding and managing the expectations of the client, users } \\
\text { and communities affected by the project }\end{array}$ & 4.59 & 0.51 & 5 & 3.12 & 1.01 & 20 \\
\hline $\begin{array}{l}\text { Honesty and integrity: Professional and personal credibility and a respect for the } \\
\text { organisation's values }\end{array}$ & 4.59 & 0.62 & 5 & 3.58 & 0.98 & 5 \\
\hline Risk analysis: The ability to identify and pre-empt risk, and to avoid and militate against it & 4.58 & 0.6 & 7 & 2.9 & 1.03 & 22 \\
\hline $\begin{array}{l}\text { Time management: The management of personal and project time to meet specific } \\
\text { objectives and timely completion }\end{array}$ & 4.57 & 0.63 & 8 & 3.46 & 0.93 & 9 \\
\hline $\begin{array}{l}\text { Communication: Communicating clearly and effectively. through appropriate verbal and } \\
\text { written presentations }\end{array}$ & 4.56 & 0.61 & 9 & 3.36 & 0.81 & 10 \\
\hline $\begin{array}{l}\text { Quality management: The control of the quality of the project to ensure that it satisfies the } \\
\text { needs for which it was undertaken }\end{array}$ & 4.53 & 0.67 & 10 & 3.33 & 1.02 & 12 \\
\hline $\begin{array}{l}\text { Project integration: The co-ordination of the various elements of the project to achieve the } \\
\text { desired objectives }\end{array}$ & 4.47 & 0.58 & 11 & 3.49 & 0.98 & 7 \\
\hline $\begin{array}{l}\text { Problem solving: The ability to gather and analyse data, identify central issues and problems, } \\
\text { and develop possible solutions }\end{array}$ & 4.46 & 0.73 & 12 & 3.66 & 0.75 & 3 \\
\hline $\begin{array}{l}\text { Interpersonal skills: The ability to manage relationships and to influence stakeholders } \\
\text { lowards project objectives }\end{array}$ & 4.44 & 0.66 & 13 & 3.35 & 0.86 & 11 \\
\hline $\begin{array}{l}\text { Motivating: The ability to stimulate the project team to achieve the required project } \\
\text { objectives }\end{array}$ & 4.41 & 0.76 & 14 & 3.25 & 0.97 & 14 \\
\hline
\end{tabular}


The original raw data was replaced with the re-scaled data provided in Table 1, and subjected to descriptive statistical analysis. The mean values and standard deviations $(\delta)$ for the perceived 'importance' and 'evidence' of each competency were calculated and ranked, and are presented in Table 2. Although certain of the competencies received low ratings, the lowest was 3.37 , which indicates that it was still between medium and high importance.

\section{Core Competencies}

By definition, core competencies are required to be generic and few in number (Tampoe, 1994). To simplify the list of 28 competencies, they were subjected to principal component (factor) analysis (Zikmund, 1997). A seven-factor solution was accepted by virtue of all factors having Eigen-values $>1$, and the factors being readily interpretable as presented in Table 3.

The factors were named according to the competencies that loaded on to them to suggest a new set of core competencies, and they were ranked according to the average scores of the contributing competencies. The names represent the core competencies required of South African project managers in the engineering, construction and information technology fields.

The factors were tested for reliability using the Cronbach Alpha Coefficient. The resulting scores demonstrated some variation, and with the exception of factor six (staff development), all of the factors were above the accepted 0.5 level (Bendixen, Cronson \& Abratt, 1991). The lower value for factor six is likely to be the result of the inclusion of lesser loading factors, and does not warrant its exclusion as a core competency.

\section{Factor one: planning and controlling}

'Planning' and 'controlling' are the statements constituting this factor. This strongly affirms the importance of project tools and planning methodologies in project management. The average competency score of 4.72 is the highest of the core competencies, which is understandable when considering that these competencies are ranked first and third respectively for overall importance. This core competency confirms that skills in project management planning and control techniques are central to the practice of project management. Similar clusters were recorded in previous international studies (Posner, 1987; Thamhain, 1991; Pettersen, 1991)

\section{Factor two: personal influence}

The competencies 'motivating', 'honesty' and 'integrity' load on to this factor. This combination is dominated by 'motivating', which confirms the role of the personal influence of the project manager. The factor average is a high

Table 3 Factor analysis of core competencies

\begin{tabular}{|c|c|c|c|c|c|}
\hline Rank & Name & $\begin{array}{l}\text { Contributing } \\
\text { competencies }\end{array}$ & $\begin{array}{l}\text { Rotated factor } \\
\text { loading }\end{array}$ & $\begin{array}{l}\text { Cronbach Alpha } \\
\text { coefficient }\end{array}$ & $\begin{array}{c}\text { Factor } \\
\text { average }\end{array}$ \\
\hline \multirow[t]{2}{*}{1.} & Planning and controlling & Planning & -0.650 & 0.495 & 4.72 \\
\hline & & Controlling & -0.486 & & \\
\hline \multirow[t]{2}{*}{2.} & Personal influence & Motivating & -0.656 & 0.619 & 4.50 \\
\hline & & Honesty and integrity & -0.496 & & \\
\hline \multirow[t]{7}{*}{3.} & Goal focus & Project integration & -0.684 & 0.728 & 4.48 \\
\hline & & Scope management & -0.589 & & \\
\hline & & Human resources & -0.555 & & \\
\hline & & Stakeholder management & -0.512 & & \\
\hline & & Delegation & -0.444 & & \\
\hline & & Communication & -0.428 & & \\
\hline & & Interpersonal skills & -0.407 & & \\
\hline \multirow[t]{3}{*}{4.} & Problem solving & Problem solving & 0.463 & 0.531 & 4.42 \\
\hline & & Quality management & 0.368 & & \\
\hline & & Conflict resolution & 0.357 & & \\
\hline \multirow[t]{3}{*}{5.} & Team leadership & Team building & 0.694 & 0.526 & 4.35 \\
\hline & & Delegation & 0.399 & & \\
\hline & & Decisiveness & 0.355 & & \\
\hline \multirow[t]{3}{*}{6.} & Project team development & Training of team & 0.635 & 0.419 & 3.98 \\
\hline & & Human resources & 0.319 & & \\
\hline & & Interpersonal skills & 0.299 & & \\
\hline \multirow[t]{5}{*}{7.} & Project context & Sourcing of funds & 0.693 & 0.709 & 3.80 \\
\hline & & Legislation awareness & 0.567 & & \\
\hline & & Global mobility & 0.552 & & \\
\hline & & Sensitivity to market & 0.477 & & \\
\hline & & Financial management & 0.424 & & \\
\hline
\end{tabular}


4.50, and ranks this as the second highest competency score. This is supported by the qualitative data results which place 'personal charisma and commitment' as the joint highest additional competency. One respondent recorded that a project manager should be 'a dynamic hard worker, who sets the example and sets the standards". The inclusion of "honesty and integrity' clearly acknowledges the inclusion of values as part of the competency as raised by Meyer et al. (1996). In addition, it demonstrates the importance of personality traits to South African project managers. However, this finding is not universally supported, and Zimmerer et al. (1998) recorded that 'charismatic personality' was among the lowest rated behaviours among North American project managers.

\section{Factor three: goal focus}

The competencies 'stakeholder management', 'project integration', 'scope management' and 'human resources' load on to this factor, supported by 'delegation', 'interpersonal skills' and 'communication'. This factor suggests the ability to manage project stakeholders and to co-ordinate their involvement with the project. The average score of 4.48 indicates the importance of this competency, which also featured prominently in the content analysis of the qualitative data. It would appear that this is a universally accepted competency. Similar clusters around 'interpersonal relations' were recorded by Jiang et al. (1998) and Pettersen (1991). Most South African projects are managed around a network of relationships, including the involvement of various and different stakeholders (Brown, 1998).

\section{Factor four: problem solving}

'Problem solving' is the dominant competency loading on to this factor, with slight contributions from 'quality management' and 'conflict resolution'. Although the factor average is relatively high and the Cronbach Alpha value is acceptable, the poor loadings may suggest that there are other possible interpretations of this factor. Problem solving also represents a departure from international studies. Although the study by Pettersen (1991) recognises this as a core competency, none of the other research acknowledges the imponance of this ability. It is possible that this competency is specific to a developing country like South Africa.

\section{Factor five: team leadership}

This factor is characterised by the 'team building' competency, with support from 'delegation 'and 'decisiveness'. The high average score of 4.35 demonstrates that this attributional competency is important to project management. This suggestion is confirmed by the qualitative data which reveals that 'leadership personality' was the third highest rated additional competency. One respondent advised that a project manager should 'concentrate on the human aspects of the team. because if you look after the people. the people will look after the project'. Leadership skill is recognised as a core competency by a host of international studies. although certain of these included a wider spectrum of competencies in this cluster (Thamhain, 1991; Jiang et al., 1998: Posner. 1987). Project personnel are invariably drawn from a variety of contexts, and it is necessary for the project manager to provide effective leadership (Eisiendel. 1987). In addition.
Zimmerer et al. (1998) recorded that positive leadership was the single overriding factor contributing to a project's success or failure.

\section{Factor six: project team development}

The competency 'training project team' loads heavily on to this factor, and is supported by 'human resources' and 'interpersonal skills'. The average score is acceptably high at 3.98 , but the low Cronbach Alpha value suggests that these competencies are not closely associated. Several international studies identify project team development as a core competency (Zimmerer et al., 1998; Pettersen, 1991; and Jiang et al., 1998).

\section{Factor seven: project context}

The competencies which load onto this factor indicate the importance of exogenous forces which act on the project. References to 'sourcing of funding', 'legislation awareness', 'global mobility' and 'sensitivity to market' all suggest the need to understand the economics and context within which the project is executed. Although this factor has the lowest average factor score of 3.80 , the high Cronbach Alpha value of 0.709 demonstrates the close !inkages between the competencies in this factor. The project context is discussed in project management literature (PMI, 1996; Ashrafi, Wideman \& Hartman, 1998), but it has not appeared as a competency in any previous study. 'Project context' might therefore represent a cluster of skills which are specific to our country, and thereby confirm the assertion by Brown (1998) that South African project managers face problems that are contextually different from those of their international counterparts.

Interestingly, a prominent international core competency which did not emerge from this study was 'technical knowledge'. It is possible that the nature of the industries in this sample are not as dependent on the high level of technical knowledge required in space exploration, medical and scientific projects. Although this was a dominant cluster in a number of studies (Lockyer et al., 1996; Thamhain, 1991; Zimmerer et al. 1998). it was poorly represented in this study. with a highest loading on any single factor of only 0.28 . Table 2 confirms that this competency was not regarded as particularly important by respondents but was rated as the second most evident competency.

The findings reflected in Table 3 lend themselves to graphic representation. This model is ordered around the three highest loading core competencies (namely goal focus, planning and controlling, and personal influence) which are located at the vertices. Three other core competencies are related to these themes. and are arranged between them. The seventh factor, context, impacts on the entire model.

\section{Qualitative data}

Of the respondents. $31 \%$ made use of the open-ended question to list additional competencies not included in the survey. These competencies were then subjected to content analysis with the most frequently mentioned competencies being: personal charisma and commitment. the use of project management planning tools. leadership. costing skills. flexibility and people management. It is noteu orthy that although these factors were not identified as competencies in the 


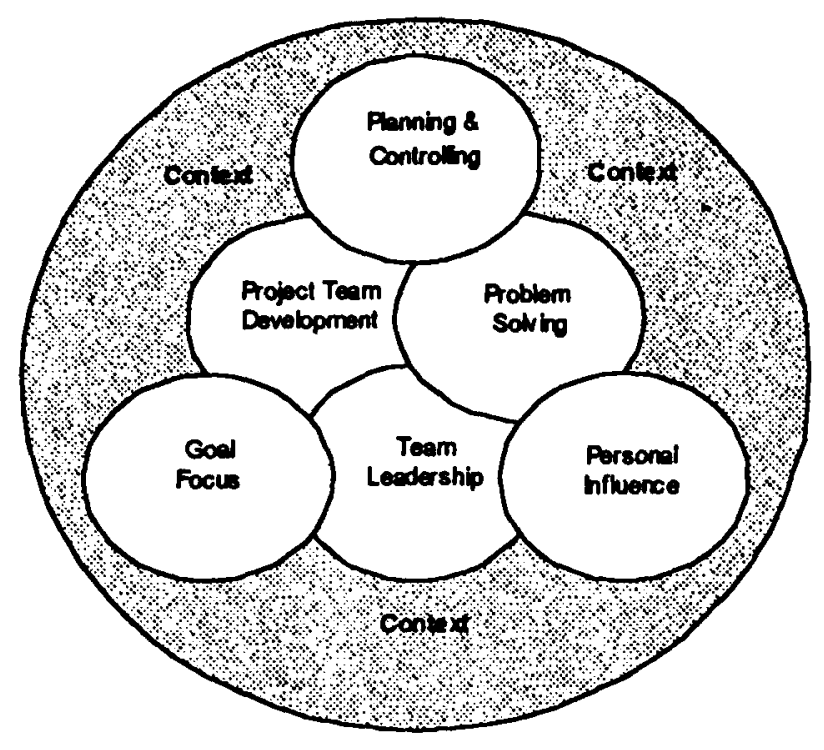

Figure 1 A South African competency model for project managers in engineering, construction and information technology

questionnaire, four out of the six additional competencies emerged from the core competencies which were identified by factor analysis.

\section{Training needs}

The principal training needs within project management were identified by establishing the gap between the level of importance of each competency, and the perceived level of evidence of its occurrence in the profession. The two sets of re-scaled data were then subjected to paired ' $t$ '-tests to establish which constructs evoked significantly different responses for 'importance' and 'evidence'. On the basis of this test, 27 of the 28 competencies were identified as representing significant training needs, with the exception of only 'technical knowledge'. The reason for this was given by a respondent who commented that project managers 'are often technical people moving into project management'.

The training needs were ranked by the size of the gap between the mean scores for 'importance' and 'evidence' of each competency. The top ten training needs are presented in Table 4.

It is interesting to note that training needs such as risk analysis, stakeholder management and legislation awareness are closely related to working in a developing country like South Africa. In these environments, projects are subject to political and economic uncertainty, crime and labour unrest, currency fluctuations, economic recession, changes in government legislation, and high levels of awareness of political and personal rights.

\section{Project management as a generic profession}

Additional analyses were performed to determine whether there was significant variance in responses relating to the demographic variables (industry, age, length of experience, qualifications and sex). The re-scaled data was subjected to two-sample ' $t$ '-tests where there were two categories, and Anova tests where there were three or more categories. Of the 140 variability tests conducted at a $5 \%$ significance level,
Table 4 Training needs of project managers in the construction, engineering and information technology fields

\begin{tabular}{lcc}
\hline Competency & Score & Rank \\
\hline Risk analysis & 1.68 & 1 \\
Stakeholder management & 1.47 & 2 \\
Scope management & 1.42 & 3 \\
Financial skills & 1.27 & 4 \\
Communication & 1.21 & 5 \\
Quality management & 1.20 & 6 \\
Motivating & 1.16 & 7 \\
Cross cultural skills & 1.15 & 8 \\
Legislation awareness & 1.14 & 9 \\
Decisiveness & 1.12 & 10 \\
\hline
\end{tabular}

only seven significant differences were found. This result confirms that project management competencies are generic in nature, and is consistent with previous findings by Crawford (1998) and Jiang et al. (1998).

Three of the 28 competencies differed significantly between the engineering/construction and information technology/information systems fields. In particular, 'legislation awareness' was more highly regarded as a competency in construction/engineering than in IT/IS, probably as a result of recently promulgated labour legislation. In contrast, 'risk management' and 'training of team' were viewed as being of greater importance to IT/IS. Likely explanations are that risk is particularly high in IT/IS, while training is essential to address the shortfall of skills in this rapidly expanding market.

The age and experience Anova analyses revealed that ' $\mathrm{glo}$ bal mobility' was significantly more important to younger, less experienced respondents than their older counterparts.

The tests for variance between male and female project managers revealed only one significant difference, the perceived importance of 'cross cultural skills'. Female project managers view the ability to communicate and to establish relationships across different cultures as more important than their male colleagues do. The different levels of qualification were collapsed to produce two groups; respondents with and without degrees. The respondents without degrees considered 'interpersonal skills' and the ability to manage relationships to be of significantly less importance than respondents with degrees.

In spite of these few variances, the overall results of the variance tests add credence to the notion that project management competencies are generic across a range of demographic variables. This has very important implications for both government and project management trainers, and suggests that the same certification criteria and study curriculum could be applied to project managers irrespective of their sex, age, experience, qualification or industry sector.

\section{Conclusion}

This study has established the core competencies required of project managers operating in the construction, engineering and information technology fields, and identified current training needs. The survey has also confirmed the finding that 
project management is a generic skill with common competencies across these industries and a range of demographic variables. It illustrates, however, that South African project managers in these fields require a number of competencies which are not reflected in international project management standards.

Although project managers show a high level of technical skills, industry trainers will need to lend additional emphasis to particular areas such as risk analysis, interpersonal skills and cultural sensitivity in their training programmes. Also, Government and the Standards Generating Body will need to take cognisance of competencies such as personal influence, problem solving and project team development when faced with the formulation of certification standards for the profession.

\section{References}

Ashrafi, R., Wideman, M. \& Hartman, F. 1998. Current and future challenges and their impact on project management, 29th Annual Project Management Institute Symposium, Long Beach, California, October 9-15, Proceedings of the 29th Annual Project Management Institute Seminars \& Symposium.

Barker, D.R. 1992. Managerial competencies of the clergy. Unpublished MM Research Report. Johannesburg: University of the Witwatersrand.

Bartlett, C.A. \& Ghosal, S. 1990. Matrix organisations, a state of mind, Harvard Business Review, 68: 138-142.

Bendixen, M.T., Cronson, D. \& Abratt, R. 1991. Consumer perceptions of a perilous product: international tourism to South Africa, South African Journal of Business, Management, 27(4): 71-81

Bendixen, M.T. \& Sandler, M. 1994. Converting verbal scales to interval scales using correspondence analysis. Unpublished Working Paper. Johannesburg: University of the Witwatersrand.

Boyatzis, R.E. 1982. The competent manager, a model for effective performance. London: John Wiley

Brown, R.B. 1993. Meta-competence: a recipe for reframing the competence debate, Personnel Review, 22(6): 25-36.

Brown, C.J. 1998. A South African project management curriculum, ProjectPro, 8(2): 33-39.

Cleland, D.1. 1991. The age of project management, Project Management Journal, 22(1): 19-24

Crawford, L. 1997. Developmental assessment of project management competence: status report: June 1997. Unpublished Research Article. Sydney: University of Technology.

Crawford, L. 1998. Standards for a global profession - project management, 29th Annual Project Management Institute Symposium, Long Beach, California, October 9-15, Proceedings of the 29th Annual Project Management Institute Seminars \& Symposium.

Cresswell, J. 1995. Managerial and service competencies of attorneys. Unpublished MM Research Report. Johannesburg: University of the Witwatersrand

Einsiedel, A.A. 1987. Profile of effective project managers, Project Management Journal, 18(5): 51-56.

Frylink, B.L. 1989. Competencies required of first line managers to manage change successfully. Unpublished MM Research Report Johannesburg: University of the Witwatersrand.

Garrick, J. \& McDonald, R. 1992. Competence standards for industry trainers: alternate models, Journal of European Industrial Training, 16(7): 16-20.

Griggs, L. \& Louw, L. 1995. Diverse teams: breakdown or breakthrough?, Training \& Development, 49/(10): 22-29.

Harrison, F.L. 1983. Advanced project management. Hants: Gower Publishing Company Limited.

IMD. 1999. The world competitiveness yearbook. Laussanne: Swit- zerland, p. 287

Jiang J., Klein, G. \& Margulis, S. 1998. Important behavioural skills for IS project managers: the judgements of experienced IS professionals, Project Management Journal. 29(1): 39-43.

Kooyman, B. \& Sargent, S. 1998. A potential role for competencies standards in the global marketplace, 1998 Global Project Management Forum, Australia, August.

Lockyer, K. \& Gordon, J. 1996. Project management and project network techniques. 6th ed. London: Pitman publishing.

Meyer, T. \& Semark, P. 1996. A framework for the use of competencies for achieving competitive advantage, South African Journal of Business Management, 27(4): 96-103.

Meyer, T. 1996. Creating competitiveness through competencies, currency for the 21 st Century. Randburg: Knowledge Resources (Pty) Ltd.

Overmeyer, G.L. 1997. Career management competencies for a new world of work. Unpublished MM Research Report. Johannesburg University of the Witwatersrand

Peters, T. 1992. Liberation management: necessary disorganisation for the nanosecond nineties. London: McMillan.

Pettersen, N. 1991. Selecting project managers: an integrated list of predictors, Project Management Journal, 22(2): 21-26.

Pinto, J.K. \& Kharbanda, O.P. 1996. Project management and conflict resolution, Project Management Journal, 26(4): 45-54.

Posner, B.Z. 1987. What it takes to be a good project manager, Project Management Journal, 18(1): 51-54.

Project Management Institute. 1996. A guide to the project management book of knowledge. Upper Darby: Project Management Institute.

Reich, R.B. 199I. The work of nations: preparing ourselves for 21 st century capitalism. New York: Knopf.

Sattler, M. \& Neights, G. 1998. Beyond PMP certification - a performance-based approach to cenifying project managers, $29 \mathrm{th}$ Annual Project Management Institute Symposium, Long Beach, California, October 9-15.

Stewart, T.A. 1995. The corporate jungle spawns a new species: the project manager, Fortune, 132(6): 179-180.

Stewar, J. \& Hamlin, B. 1992. Competence based qualifications: the case against change, Journal of European Industrial Training, 16(7): 21-32.

Tampoe, M. 1994. Exploiting the core competencies of your organisation, Long Range Planning, 27(4): 66-77.

Thamhain, H.J. 1991. Developing project management skills, Project Management Journal, 22(3): 39-44.

Toney, F. 1998. The fortune 500 project management benchmarking forum defines competencies, 29th Annual Project Management Institute Symposium, Long Beach, Califomia, October 9-15, Proceedings of the 29th Annual Project Management Institute Seminars \& Symposium

Turner, D \& Crawford. M. 1992. Managing current and future competitive performance : the role of competence. Sydney: Australian Graduate School of Management. Centre for Corporate Change, pp. 1-26.

Wills. S. 1993. MCI and the competency movement: the case so far, Journal of European Industrial Training, 17(1): 9-11.

Woodruffe, C. 1993. What is meant by a competency?, Leadership and Organisation Development Journal, 14(1): 29-36.

Zikmund, W.G. 1997. Business research methods. Sth ed. Orlando: The Dryden Press.

Zimmerer, T. \& Yasin, M. 1998. A leadership profile of American project managers, Project Management Journal, 29(1): 31-38. 